\title{
DETERMINAN FINANCIAL DISTRESS PADA PERUSAHAAN MANUFAKTUR YANG TERDAFTAR DI BURSA EFEK INDONESIA TAHUN 2016-2018
}

\author{
Sopiyati \\ saisasopi597@gmail.com \\ Jurusan Akuntansi Fakultas Ekonomi dan Bisnis Universitas Mataram \\ Nina Karina Karim \\ ninakarim@unram.ac.id \\ Jurusan Akuntansi Fakultas Ekonomi dan Bisnis Universitas Mataram \\ Zuhrotul Isnaini \\ zuhrotul.isnaini@unram.ac.id \\ Jurusan Akuntansi Fakultas Ekonomi dan Bisnis Universitas Mataram
}

\begin{abstract}
ABSTRAK
Penelitian ini bertujuan untuk mengetahui determinan financial distress atau faktorfaktor yang mempengaruhi financial distress. Jenis penelitian yang digunakan adalah penelitian asosiatif kausal dengan pendekatan kuantitatif. Populasi dalam penelitian ini adalah perusahaan manufaktur yang terdaftar di Bursa Efek Indonesia tahun 2016-2018. Pemilihan sampel yaitu berdasarkan metode purposive sampling, sehingga diperoleh sampel sebanyak 80 perusahaan. Jenis data yang digunakan dalam penelitian ini adalah data sekunder berupa laporan tahunan perusahaan. Metode analisis yang digunakan dalam penelitian ini adalah analisis regresi linear berganda. Hasil penelitian menunjukkan bahwa variabel profitabilitas, likuiditas, aktivitas berpengaruh positif dan signifikan terhadap financial distress. Sedangkan leverage berpengaruh negatif dan signifikan terhadap financial distress.
\end{abstract}

Kata Kunci : Financial Distress, Profitabilitas, Likuiditas, Leverage, Aktivitas

\section{ABSTRACT}

This research aims to know the determinants of financial distress or the factors that affect financial distress. This type of research is a causal associative research with a quantitative approach. The population in this study are manufacturing companies listed on the Indonesia Stock Exchange in 2016-2018. The sample selection is based on the purposive sampling method, in order to obtain a sample of 80 companies. The type of data used in this study is secondary data in the form of company annual reports. The analytical method used in this research is multiple linear regression analysis. The results showed that the variables of profitability, liquidity, activity has a positive and significant effect on financial distress. Meanwhile, leverage has a negative and significant effect on financial distress.

Keywords : Financial Distress, Profitability, Liquidity, Leverage, Activities

\section{PENDAHULUAN}

Perkembangan dunia bisnis di era globalisasi serta ketatnya persaingan dalam mencapai tujuan dan peningkatan laba, mendorong perusahaan untuk memperkuat 
fundamental manajemen agar mampu bertahan serta terhindar dari kesulitan keuangan yang mengarah pada kebangkrutan (Putri, 2019).

Tujuan didirikannya suatu perusahaan menurut Ratna dan Marwati (2018) adalah memaksimumkan keuntungan perusahaan dan kemakmuran pemilik perusahaan. Maka dari itu pihak manajemen harus dapat menghasilkan keuntungan yang optimal dan pengendalian yang saksama terhadap kegiatan operasional, terutama yang berkaitan dengan keuntungan perusahaan.

Menurut IMF (International Monetary Bank) pada Januari 2016, dalam World Economic Outlook Update, pertumbuhan perekonomian di Cina mengalami perlambatan karena tengah menjalani transisi model pertumbuhan yang lebih bertumpu pada konsumsi dan sektor jasa di masa depan. Hal tersebut bisa memicu efek berantai ke negara-negara lain karena selama ini Cina merupakan konsumen produk-produk komoditas dan negara dagang terbesar bagi sejumlah negara berkembang termasuk Indonesia. Selain itu, kebijakan bank sentral AS (Federal Reserve) yang meninggalkan rezim bunga nol persen sejak akhir tahun 2015. Kebijakan ini akan semakin memperkuat mata uang dolar dan memperketat pembiayaan global.

As (2019) menjelaskan bahwa banyak hal yang ditimbulkan dari kondisi ketidakstabilan ekonomi seperti menurunnya investasi secara global baik dalam infrastruktur, perdagangan, maupun industri yang berdampak negatif pada berbagai sektor vital perekonomian khususnya perusahaan tak terkecuali perusahaan manufaktur yang ada di Indonesia. Perusahaan manufaktur merupakan salah satu sektor penting dalam pembangunan ekonomi nasional (bps.go.id). Namun, data world bank menunjukkan bahwa kontribusi sektor industri manufaktur terhadap Produk Domestik Bruto (PDB) di Indonesia melemah dari tahun 2015 yang mencapai 20,99\% menjadi 19,86\% di tahun 2018 (data.worldbank.org).

Di dalam penelitian Sari (2019), ia berpendapat bahwa indikasi terjadinya kesulitan keuangan atau financial distress dapat diketahui dari kinerja keuangan suatu perusahaan. Kinerja keuangan dapat diperoleh dari informasi akuntansi yang berasal dari laporan keuangan melalui analisis rasio keuangan. Penelitian-penelitian yang mengkaji determinan financial distress menunjukkan hasil yang beragam. Determinan yang pertama yakni rasio profitabilitas. Rahmayanti dan Hadromi (2017) menunjukkan bahwa profitabilitas berpengaruh negatif terhadap financial distress karena semakin tinggi rasio profitabilitas maka semakin kecil kemungkinan perusahaan mengalami financial distress. Hasil penelitian ini didukung oleh penelitian Aini (2019).

Berdasarkan penelitian yang dilakukan oleh Atina dan Rahmi (2019) menunjukkan bahwa likuiditas mempunyai pengaruh negatif terhadap financial distress karena setiap perusahaan yang mampu membayar utang lancar dengan baik, maka semakin kecil kemungkinan perusahaan mengalami kondisi financial distress.

Penelitian yang dilakukan oleh Utami (2015) menunjukkan bahwa leverage berpengaruh positif terhadap financial distress karena semakin tinggi utang semakin besar pula kemungkinan terjadinya financial distress. Penelitian yang dilakukan oleh Saputra (2019) menunjukkan bahwa aktivitas berpengaruh negatif terhadap financial distress karena semakin tinggi rasio aktivitas maka semakin kecil perusahaan akan mengalami kondisi fianancial distress.

Perbedaan penelitian ini dengan penelitian-penelitian sebelumnya yaitu jumlah sampel penelitian yang digunakan dan indikator yang digunakan untuk mengukur financial distress. Oleh kerena itu, penulis berupaya mengetahui faktor-faktor yang memengaruhi financial distress melalui penelitian yang berjudul "Determinan 


\section{Risinace}

Vol. 1 No. 4 Desember 2021

Financial Distress pada Perusahaan Manufaktur yang Terdaftar di Bursa Efek Indonesia tahun 2016-2018". Berdasarkan latar belakang di atas, maka di rumuskan masalah dalam penelitian ini adalah apakah rasio profitabilitas, rasio likuiditas, rasio leverage, dan rasio aktivitas berpengaruh terhadap financial distress.

\section{TINJAUAN PUSTAKA DAN PENGEMBANGAN HIPOTESIS Teori Agensi (Agency Theory)}

Teori keagenan mencerminkan hubungan kontraktual antara agen dan prinsipal. Jensen dan Meckling (1976) menyatakan bahwa hubungan keagenan merupakan suatu kontrak di mana satu atau lebih orang (principal) memerintah orang lain (agent) untuk melakukan suatu jasa atas nama prinsipal serta memberi wewenang kepada agen membuat keputusan yang terbaik bagi prinsipal. Jika kedua belah pihak tersebut mempunyai tujuan yang sama untuk memaksimumkan nilai perusahaan, maka diyakini agen akan bertindak dengan cara yang sesuai dengan kepentingan prinsipal.

\section{Financial Distress}

Financial distress merupakan tahap penurunan kondisi keuangan yang terjadi sebelum terjadinya kebangkrutan atau dilikuidasi (Platt dan Platt, 2002). Kristanti (2019:3) menjelaskan bahwa financial distress merupakan suatu situasi ketika sebuah perusahaan tidak mampu memenuhi kewajibannya. Hal ini terjadi sebagai tanda awal sebelum pada akhirnya hal yang paling buruk akan bisa terjadi, yaitu kebangkrutan. Financial distress menurut Whitaker (1999) adalah kondisi pada saat arus kas perusahaan lebih kecil dari utang jangka panjang yang jatuh tempo.

\section{Analisis Laporan Keuangan}

Laporan keuangan adalah laporan yang diharapkan bisa memberikan informasi mengenai perusahaan, dan digabungkan dengan informasi yan lain, seperti industri, kondisi ekonomi, bisa memberikan gambaran yang lebih baik mengenai prospek dan risiko perusahaan (Hanafi dan Halim, 2016:61). Definisi analisis laporan keuangan yang dikemukan oleh Horne dan Wachowicz (2017:154) adalah seni untuk mengubah data dari laporan keuangan ke informasi yang berguna dalam pengambilan keputusan.

\section{Rasio Keuangan}

Horne dan Wachowicz (2017:163) menyatakan bahwa rasio keuangan digunakan untuk mengevaluasi kondisi keuangan dan kinerja perusahaan. Dari hasil rasio keuangan tersebut menggambarkan tingkat kesehatan perusahaan yang sangat berguna bagi pemakai laporan keuangan dalam mengambil keputusan.

\section{KERANGKA KONSEPTUAL}

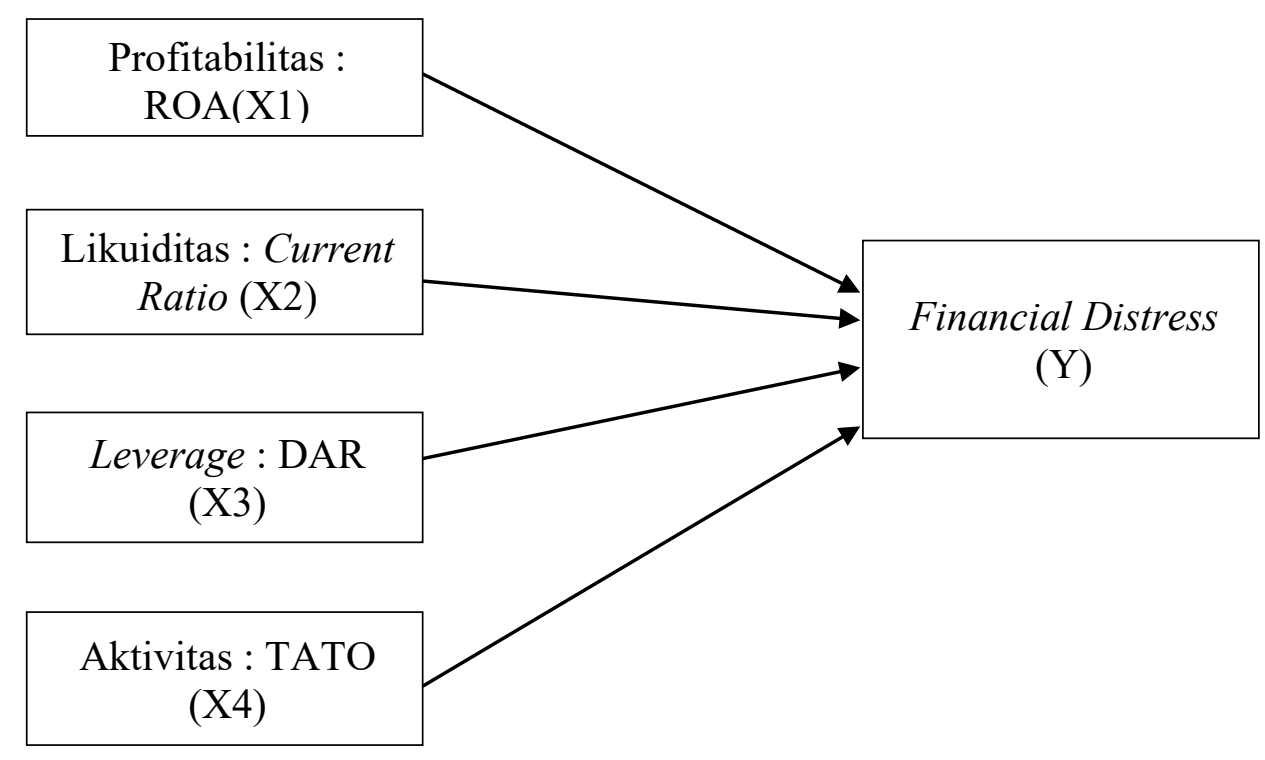




\section{PENGEMBANGAN HIPOTESIS}

\section{Pengaruh Rasio Profitabilitas Terhadap Financial Distress}

Rasio ini bertujuan untuk mengukur tingkat efektivitas manajemen dalam menjalankan operasional perusahaan. Sesuai dengan teori agensi, jika suatu perusahaan mencetak laba yang tinggi, dapat dikatakan agen berhasil dalam mengelola perusahaannya. Dengan laba yang tinggi maka akan menarik investor untuk berinvestasi,sehingga menjauhkan suatu perusahaan dari ancaman financial distress.

$\mathrm{H}_{1}$ : Rasio profitabilitas berpengaruh terhadap financial distress

Pengaruh Rasio Likuiditas Terhadap Financial Distress

Likuiditas ini berkaitan dengan seberapa besar kemampuan perusahaan dalam membiayai kewajiban jangka pendeknya yang sudah jatuh tempo. Apabila perusahaan mampu mendanai dan melunasi kewajiban jangka pendeknya dengan baik maka potensi perusahaan mengalami financial distress akan semakin kecil.

$\mathrm{H}_{2}$ : Rasio likuiditas berpengaruh terhadap financial distress.

Pengaruh Rasio Leverage Terhadap Financial Distress

Dalam artian luas dikatakan bahwa rasio leverage digunakan untuk mengukur kemampuan perusahaan untuk membayar seluruh kewajibannya baik jangka pendek maupun jangka panjang apabila perusahaan dibubarkan atau dilikuidasi (Kasmir, 2019:114). Dalam teori keagenan, kelangsungan hidup perusahaan berada di tangan agen. Apakah agen memutuskan untuk melakukan pendanaan dari pihak ketiga atau tidak. Keputusan agen mengenai pendanaan aset perusahaan sangatlah penting, karena jika total utang lebih besar dari total aset yang dimiliki perusahaan, maka perlu ditinjau lebih lanjut kinerja agen dalam mengelola perusahaan, dan hal tersebut mengakibatkan perusahaan rentan terhadap kesulitan keuangan atau financial distress.

$\mathrm{H}_{3}$ : Rasio leverage berpengaruh terhadap financial distress.

\section{Pengaruh Rasio Aktivitas Terhadap Financial Distress}

Berdasarkan teori agensi, kegiatan pengelolaan perusahaan dilakukan oleh agen. Jika agen tidak bisa memaksimalkan penggunaan aset perusahaan, penjualan perusahaan juga tidak bisa maksimal. Semakin tinggi rasio ini berarti semakin efektif perusahaan dalam menggunakan asetnya yang menunjukkan manajemen yang baik sehingga kemungkinan perusahaan mengalami financial distress juga semakin rendah. Sebaliknya rasio yang rendah harus membuat manajemen mengevaluasi strategi, pemasarannya, dan pengeluaran modalnya (investasi).

$\mathrm{H}_{4}$ : Rasio aktivitas berpengaruh terhadap financial distress

\section{METODE PENELITIAN}

\section{Jenis Penelitian}

Jenis penelitian yang digunakan adalah penelitian asosiatif kausal dengan pendekatan kuantitatif. Populasi dalam penelitian ini adalah perusahaan manufaktur yang terdaftar di Bursa Efek Indonesia tahun 2016-2018 sebanyak 166 perusahaan. Berdasarkan metode purposive sampling yang telah dilakukan, maka diperoleh sampel yang memenuhi kriteria sebanyak 80 perusahaan tahun 2016-2018.

\section{Variabel Penelitian}

\section{Variabel Dependen (Y)}

Variabel dependen berupa financial distress yang dapat dihitung dengan rumus Altman's Z-Score (Altman, 1968) sebagai berikut:

$\mathrm{Z}=1,2 \mathrm{X} 1+1,4 \mathrm{X} 2+3,3 \mathrm{X} 3+0,6 \mathrm{X} 4+0,999 \times 5$ 


\section{Risisnaw}

Vol. 1 No. 4 Desember 2021

Keterangan:

$\mathrm{Z}=\mathrm{Z}$-Score

$\mathrm{X} 1=($ Aset Lancar-Utang Lancar $) /$ Total Aset

X2 = Laba Ditahan / Total Aset

X3 = Laba Sebelum Bunga dan Pajak / Total Aset

X4 = Nilai Pasar Saham Biasa dan Preferen / Total Utang

X5 = Penjualan $/$ Total Aset

\section{Variabel Dependen (X)}

\section{Rasio Profitabilitas}

Profitabilitas dalam penelitian ini diukur dengan ROA (Return on Asset). Rasio ini mengukur kemampuan perusahaan menghasilkan laba bersih berdasarkan tingkat aset yang tertentu. Rumus yang dapat digunakan untuk mengukur Return on Asset menurut Horne dan Wachowicz (2017:182) adalah:

\section{Rasio Likuiditas}

$$
R O A=\frac{\text { Laba Bersih }}{\text { Total Aset }}
$$

Dalam penelitian ini, rasio likuiditas diukur dengan current ratio. Rasio ini menunjukkan kemampuan perusahaan untuk membayar kewajiban jangka pendeknya dengan menggunakan aset lancarnya. Menurut Horne dan Wachowicz (2017:167) current ratio dapat dihitung dengan rumus sebagai berikut:

\section{Rasio Leverage}

$$
\text { Current Ratio }=\frac{\text { Aset Lancar }}{\text { Utang Lancar }}
$$

Dalam penelitian ini rasio yang digunakan untuk mengukur leverage adalah Debt to Asset Ratio (DAR). Rasio ini merupakan rasio utang yang digunakan untuk mengukur seberapa aktiva perusahaan dibiayai oleh utang atau seberapa besar utang perusahaan berpengaruh terhadap pengelolaan aktiva. Rumus yang dapat digunakan untuk mengukur Debt to Asset Ratio menurut Horne dan Wachowicz (2017:170) adalah:

$$
D A R=\frac{\text { Total Utang }}{\text { Total Aset }}
$$

\section{Rasio Aktivitas}

Rasio aktivitas dalam penelitian ini diukur dengan Total Asset Turnover (TATO). Rasio ini digunakan untuk mengukur perputaran semua aktiva yang dimiliki perusahaan dan berapa jumlah penjualan yang diperoleh dari tiap rupiah aktiva (Kasmir, 2019:113). Menurut Horne dan Wachowicz (2017:180) Total Asset Turnover (TATO) dapat dihitung dengan rumus sebagai berikut:

$$
\text { TATO }=\frac{\text { Penjualan }}{\text { Total Aset }}
$$

\section{HASIL DAN PEMBAHASAN \\ Statistik Deskriptif}

Statistik deskriptif menggambarkan nilai minimum, maksimum, mean, dan standar deviasi pada masing-masing variabel penelitian. Analisis ini diolah menggunakan program SPSS 25 dapat dilihat pada tabel 4.1. sebagai berikut: 
Tabel 4.1.

Hasil Statistik Deskriptif

\begin{tabular}{lrrrrr}
\hline \multicolumn{1}{c}{ Keterangan } & N & \multicolumn{1}{c}{ Min } & \multicolumn{1}{c}{ Max } & \multicolumn{1}{c}{ Mean } & \multicolumn{1}{c}{$\begin{array}{c}\text { Std. } \\
\text { Deviation }\end{array}$} \\
\hline Financial Distress & 164 & -.088 & 9.997 & 2.68109 & 1.748496 \\
Profitabilitas & 164 & -.220 & .262 & .03191 & .064795 \\
Likuiditas & 164 & .360 & 5.822 & 1.89680 & 1.150409 \\
Leverage & 164 & .133 & 1.823 & .48385 & .245452 \\
Aktivitas & 164 & .128 & 3.105 & .97028 & .470186 \\
\hline
\end{tabular}

Sumber : Data diolah (2020)

Analisis Regresi Linear Berganda

Analisis ini dilakukan untuk menguji pengaruh profitabilitas $\left(\mathrm{X}_{1}\right)$, likuiditas $\left(\mathrm{X}_{2}\right)$, leverage $\left(\mathrm{X}_{3}\right)$, dan aktivitas $\left(\mathrm{X}_{4}\right)$ terhadap financial distress $(\mathrm{Y})$. Hasil analisis regresi linear berganda dalam penelitian ini dapat dilihat pada tabel 4.2. sebagai berikut:

Tabel 4.2.

Hasil Analisis Regresi Linear Berganda

\begin{tabular}{lccccc}
\hline Variabel & B & Std. Error & Beta & t & Sig. \\
\hline (Constant) & -.119 & .033 & & -3.629 & .000 \\
Profitabilitas & .126 & .033 & .217 & 3.874 & .000 \\
Likuditas & .164 & .060 & .247 & 2.721 & .007 \\
Leverage & -.161 & .074 & -.198 & -2.177 & .031 \\
Aktivitas & .363 & .047 & .426 & 7.736 & .000 \\
\hline
\end{tabular}

Uji Normalitas

Sumber: Data diolah (2020)

Hasil pengujian normalitas disajikan pada tabel 4.3. sebagai berikut:

Tabel 4.3.

Hasil Uji Normalitas

\begin{tabular}{llr}
\hline & & $\begin{array}{c}\text { Unstandardized } \\
\text { Residual }\end{array}$ \\
\hline $\mathrm{N}$ & & 164 \\
Normal Parameters & Mean & .0000000 \\
& Std. Deviation & 21.77062396 \\
Most Extreme & Absolute & .066 \\
Differences & Positive & .055 \\
& Negative & -.066 \\
Test Statistic & & .074 \\
Asymp. Sig. (2-tailed) & & .074 \\
\hline
\end{tabular}

Berdasarkan uji normalitas yang dilakukan dengan uji statistik non-parametrik Kolmogorov-Smirnov (K-S), didapatkan nilai Asymp.Sig. (2-tailed) sebesar 0.074. Dengan nilai signifikan $>0.05$ sehingga dapat disimpulkan bahwa $\mathrm{H}_{0}$ diterima yang artinya data residual berdistribusi secara normal. Sehingga model regresi pertama dinyatakan memenuhi asumsi uji normalitas.

\section{Uji Multikolonieritas}

Uji multikolinieritas bertujuan untuk menguji apakah model regresi ditemukan adanya korelasi antar variabel bebas.Uji multikolinieritas dihitung dengan Variance Inflation Factor (VIF). Suatu model regresi dikatakan bebas dari multikolinieritas 


\section{Risinac}

Vol. 1 No. 4 Desember 2021

apabila nilai Tolerance di atas 0.10 atau sama dengan VIF di bawah 10 (Ghozali, 2018:107). Adapun hasil uji multikolonieritas dapat dilihat pada tabel 4.4. sebagai berikut:

Tabel 4.4. Hasil Uji Multikolonieritas

\begin{tabular}{lccl}
\hline \multicolumn{1}{c}{ Variabel Bebas } & Tolerance & VIF & \multicolumn{1}{c}{ Kesimpulan } \\
\hline Profitabilitas & .972 & 1.029 & $\begin{array}{l}\text { Tidak Terjadi } \\
\text { Multikolonieritas } \\
\text { Tidak Terjadi } \\
\text { Likuiditas }\end{array}$ \\
Leverage & .877 & 1.140 & $\begin{array}{l}\text { Multikolonieritas } \\
\text { Tidak Terjadi } \\
\text { Multikolonieritas } \\
\text { Aktivitas }\end{array}$ \\
\hline
\end{tabular}

Sumber: Data diolah (2020)

Nilai tolerance dari setiap variabel independen $>0.10$ dan nilai VIF dari setiap variabel independen $<10$, sehingga dapat disimpulkan bahwa variabel independen tidak saling terikat atau bebas dari multikolonieritas.

Uji Autokorelasi

Uji autokorelasi pada penelitian ini menggunakan uji Cochrane-Orcutt dengan pengambilan keputusan $\mathrm{du}<\mathrm{d}<4$-du yang menunjukkan tidak adanya korelasi. Hasil uji autokorelasi disajikan pada tabel 4.5. sebagai berikut:

Tabel 4.5. Hasil Uji Autokorelasi

\begin{tabular}{rrrr}
\hline \multicolumn{1}{l}{ R } & R Square & Adjusted R Square & \multicolumn{1}{c}{ Durbin-Watson } \\
\hline .842 & .709 & .701 & 1.894 \\
\hline
\end{tabular}

Sumber: Data diolah (2020)

Berdasarkan hasil pengujian autokorelasi dengan uji Cochrane-Orcutt yang terdapat pada tabel 4.5, terlihat bahwa nilai Durbin-Watson sebesar 1.894. Jika dibandingkan dengan nilai tabel menggunakan signifikan 5\% jumlah sampel 164 (n) dan jumlah variabel independen $4(\mathrm{k}=4)$, maka tabel Durbin-Watson didapatkan nilai du $=1.78198<1.894<4-1.78098$. Jadi, dapat disimpulkan tidak terdapat autokorelasi positif maupun negatif pada model regresi penelitian ini.

\section{Uji Heteroskedastisitas}

Pada penelitian ini uji heteroskedastisitas dapat dideteksi dengan cara menggunakan Uji Glejser. Model regresi yang baik adalah yang hemoskedastisitas atau tidak terjadi heteroskedastisitas. Hasil uji heteroskedastisitas pada penelitian ini dapat dilihat pada tabel 4.6. sebagai berikut:

Tabel 4.6. Hasil Uji Heteroskedastisitas

\begin{tabular}{lcc}
\hline \multicolumn{1}{c}{ Variabel } & Sig. & Kesimpulan \\
\hline Profitabilitas & .712 & Bebas Heteroskedastisitas \\
Likuiditas & .223 & Bebas Heteroskedastisitas \\
Leverage & .191 & Bebas Heteroskedastisitas \\
Aktivitas & .143 & Bebas Heteroskedastisitas \\
\hline
\end{tabular}

Sumber: Data diolah (2020)

Berdasarkan hasil analisis maka dapat disimpulkan bahwa data tidak terkena heteroskedastisitas. Hal tersebut dapat dibuktikan dengan nilai signifikan setiap variabel independen yang memiliki nilai $>0.05$. 


\section{Uji Koefisien Determinasi}

Hasil uji koefisien determinasi dalam penelitian ini ditunjukkan pada tabel 4.7. sebagai berikut:

Tabel 4.7. Hasil Uji Koefisien Determinasi (Adjusted $\mathbf{R}^{2}$ )

\begin{tabular}{cc} 
Adjusted R Square & R Square \\
\hline .701 & .709 \\
\hline \multicolumn{3}{c}{ Sumber: Data diolah (2020) }
\end{tabular}

Berdasarkan tabel 4.7, diperoleh hasil bahwa nilai koefisien determinasi regresi berganda (Adjusted $\mathrm{R}^{2}$ ) adalah sebesar 0.701 atau $70.1 \%$. Hal ini mengindikasikan bahwa financial distress mampu dijelaskan sebesar 70.1\% oleh profitabilitas, likuiditas, leverage, dan aktivitas. Sedangkan sisanya yaitu sebesar 29.9\% (100\%-70.1\%) dijelaskan oleh variabel-variabel lain di luar model penelitian.

\section{Uji Statistik F}

Hasil uji F dapat dilihat dalam tabel di bawah ini:

Tabel 4.8. Hasil Uji Statistik F

\begin{tabular}{cc}
\hline Nilai $\mathbf{F}$ & Sig. \\
\hline $\mathbf{9 5 . 5 2 1}$ & $\mathbf{. 0 0 0}$ \\
\hline & Sumber: Data diolah (2020)
\end{tabular}

Berdasarkan tabel 4.8. di atas, didapat $\mathrm{F}$ hitung sebesar 95.521 dengan probabilitas sebesar 0.000 yang nilainya lebih kecil dari 0.05 . Hal ini menunjukkan bahwa semua variabel independen yaitu profitabilitas, likuiditas, leverage, dan aktivitas berpengaruh signifikan secara simultan (bersama-sama) terhadap financial distress.

\section{Uji Statistik t}

Uji t digunakan untuk mengetahui pengaruh secara parsial variabel independen terhadap variabel dependen. Pengujian dilakukan dengan menggunakan signifikan level $0,05(\alpha=5 \%)$. Hasil uji statistik t dijelaskan pada tabel 4.9 sebagai berikut:

\section{Tabel 4.9. Hasil Uji Statistik t}

\begin{tabular}{lcccc}
\hline \multicolumn{1}{c}{ Variabel } & B & t & Sig. & Kesimpulan \\
\hline Profitabilitas & .126 & 3.874 & .000 & H1 diterima \\
Likuditas & .164 & 2.721 & .007 & H2 diterima \\
Leverage & -.161 & -2.177 & .031 & H3diterima \\
Aktivitas & .363 & 7.736 & .000 & H4 diterima \\
\hline
\end{tabular}

Sumber: Data diolah (2020)

\section{PEMBAHASAN}

\section{Pengaruh Rasio Profitabilitas terhadap Financial Distress}

Hipotesis pertama yang diajukan dalam penelitian ini adalah rasio profitabilitas berpengaruh terhadap financial distress. Berdasarkan hasil analisis statistik, koefisien beta dari variabel rasio profitabilitas sebesar 0.126 dengan tingkat signifikan sebesar 


\section{Risinace}

Vol. 1 No. 4 Desember 2021

0.000 lebih kecil dari 0.05 dan nilai thitung sebesar 3.874 lebih besar dari nilai tabel sebesar 1.9751. Dari hasil tersebut maka $\mathbf{H}_{0}$ ditolak dan $\mathbf{H}_{\mathbf{a}}$ diterima yang artinya rasio profitabilitas memiliki pengaruh positif yang signifikan terhadap financial distress.

Rasio profitabilitas itu sendiri adalah rasio yang mengukur efisiensi suatu perusahaan dalam mengelola asetnya untuk menghasilkan laba (Hanafi dan Halim, 2016:74). Rasio ini merupakan salah satu rasio yang paling disoroti pada laporan keuangan, karena rasio ini mampu menunjukkan keberhasilan suatu perusahaan dalam menghasilkan laba berdasarkan penggunaan aset perusahaan tersebut. Alasan yang mungkin dapat menjelaskan mengapa rasio profitabilitas berpengaruh positif terhadap financial distress adalah di dalam aset yang tinggi bisa terjadi utang yang tinggi pula, dikarenakan perusahaan melakukan pembelian atau penambahan aset secara kredit yang menyebabkan kenaikan aset diikuti dengan meningkatnya utang perusahaan (Gunde dkk, 2017). Kondisi ini juga terjadi dikarenakan perusahaan manufaktur periode penelitian memiliki nilai rata-rata rasio profitabilitas sebesar $6.38 \%$ lebih kecil dari rata-rata rasio utangnya yaitu sebesar $51.25 \%$. Rasio profitabilitas bisa juga berpengaruh positif terhadap terjadinya financial distress dikarenakan di saat biaya tetap mengalami kenaikan berdampak pada peningkatan harga pokok penjualan yang berdampak pula pada menurunnya tingkat penjualan, sehingga profitabilitas yang diterima oleh perusahaan juga akan mengalami penurunan, sehingga terjadi peningkatan financial distress pada perusahaan tersebut (Widiaputri, 2010)

Hasil penelitian ini sejalan dengan penelitian yang dilakukan oleh Jaafar dkk (2018) didukung oleh Opitalia dan Zulman (2019) yang menyimpulkan bahwa profitabilitas berpengaruh positif secara signifikan terhadap financial distress. Namun, hasil penelitian ini bertentangan dengan penelitian Zhafirah dan Majidah (2019) dan Sari dkk (2019) yang membuktikan bahwa tidak ada pengaruh profitabilitas terhadap financial distress

\section{Pengaruh Rasio Likuiditas terhadap Financial Distress}

Hipotesis kedua yang diajukan dalam penelitian ini adalah rasio likuiditas berpengaruh terhadap financial distress. Berdasarkan hasil analisis statistik, koefisien beta dari variabel rasio profitabilitas sebesar 0.164 dengan tingkat signifikan sebesar 0.007 lebih kecil dari 0.05 dan nilai thitung sebesar 2.721 lebih besar dari nilai $t_{\text {tabel }}$ sebesar 1.9751. Dari hasil tersebut maka $\mathbf{H}_{0}$ ditolak dan $\mathbf{H}_{\mathbf{a}}$ diterima yang artinya rasio likuiditas memiliki pengaruh positif yang signifikan terhadap financial distress.

Rasio likuiditas merupakan kemampuan perusahaan untuk memenuhi liabilitas jangka pendeknya dengan menggunakan aset lancarnya (Van Horne, 2017:167). Namun dalam penelitian ini, likuiditas yang tinggi tidak sepenuhnya mampu melunasi kewajiban jangka pendeknya sehingga perusahaan dapat berpotensi mengalami financial distress. Alasan yang mungkin dapat menjelaskan mengapa rasio likuiditas berpengaruh positif terhadap financial distress dikarenakan dalam aset lancar terdapat piutang usaha dan persediaan yang bergantung pada bagaimana manajemen mengelola aset tersebut. Meskipun mempunyai likuiditas yang tinggi perusahaan belum tentu dapat memenuhi semua hutang jangka pendeknya apabila manjemen tidak dapat menggunakan aset perusahaan secara efektif dan efisien dan tidak dapat mengelola perputaran aset dengan baik (Dewi, 2019).

Hasil penelitian ini sejalan dengan penelitian yang dilakukan oleh Rahmayanti dan Hadromi (2017) yang menyimpulkan bahwa likuiditas berpengaruh positif secara signifikan terhadap financial distress. Namun, hasil penelitian ini bertentangan 
penelitian oleh Silalahi dkk (2018) dan Aini (2019) yang menyimpulkan bahwa likuiditas tidak berpengaruh secara signifikan terhadap financial distress.

\section{Pengaruh Rasio Leverage terhadap Financial Distress}

Hipotesis ketiga yang diajukan dalam penelitian ini adalah rasio leverage berpengaruh terhadap financial distress. Berdasarkan hasil analisis statistik, koefisien beta dari variabel rasio profitabilitas sebesar -0.161 dengan tingkat signifikan sebesar 0.031 lebih kecil dari 0.05 dan nilai $t_{\text {hitung }}$ sebesar -2.177 lebih kecil dari nilai $t_{\text {tabel }}$ sebesar -1.9751. Dari hasil tersebut maka $\mathbf{H}_{\mathbf{0}}$ ditolak dan $\mathbf{H}_{\mathbf{a}}$ diterima yang artinya rasio leverage memiliki pengaruh negatif yang signifikan terhadap financial distress.

Rasio leverage merupakan rasio yang digunakan untuk mengukur sejauh mana aktiva mampu membiayai utang perusahaan atau seberapa besar utang perusahaan berpengaruh terhadap pengolahan aktiva. Keputusan agen mengenai pendanaan dari pihak ketiga dalam penelitian ini sudah berhasil walaupun perusahaan memiliki total utang yang lebih besar dari total asetnya tetapi perusahaan bisa terhindar dari kemungkinan terjadinya financial distress. Artinya kinerja agen dalam mengelola perusahaan sudah efisien. Dalam penelitian ini ditemukan bahwa semakin tinggi rasio leverage semakin rendah kemungkinan terjadinya financial distress. Hal yang menyebabkan kondisi tersebut terjadi dikarenakan perusahaan yang besar biasanya sering menggunakan utang yang tinggi untuk dijadikan pengembangan dalam pengelolaan perusahaannya yang selanjutnya akan memberikan keuntungan bagi perusahaan (Aini, 2019).

Hasil penelitian ini sejalan dengan penelitian yang dilakukan oleh Masdupi dkk (2018) dan didukung oleh Opitalia dan Zulman (2019) dan Silalahi dkk (2018) yang menyimpulkan bahwa leverage berpengaruh negatif secara signifikan terhadap financial distress. Namun, hasil penelitian ini bertentangan penelitian Atina dan Rahmi (2019), Sari dkk (2019), dan Saputra (2019) yang membuktikan bahwa tidak ada pengaruh leverage terhadap financial distress.

\section{Pengaruh Rasio Aktivitas terhadap Financial Distress}

Hipotesis keempat yang diajukan dalam penelitian ini adalah rasio aktivitas berpengaruh terhadap financial distress. Berdasarkan hasil analisis statistik, koefisien beta dari variabel rasio profitabilitas sebesar 0.363 dengan tingkat signifikan sebesar

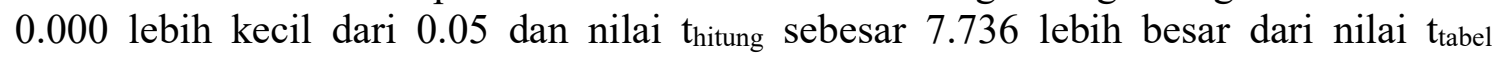
sebesar 1.9751. Dari hasil tersebut maka $\mathbf{H}_{0}$ ditolak dan $\mathbf{H}_{\mathbf{a}}$ diterima yang artinya rasio aktivitas memiliki pengaruh positif yang signifikan terhadap financial distress.

Rasio aktivitas merupakan rasio yang digunakan untuk mengukur sejauh mana efektivitas perusahaan dalam mengoptimalkan asetnya (Hanafi dan Halim, 2016:74). Rasio aktivitas yang tinggi menunjukkan manajemen telah berhasil memanfaatkan aset dalam menghasilkan penjualan. Semakin tinggi tingkat perputarannya semakin efektif perusahaan memanfaatkan asetnya dengan baik untuk menghasilkan penjualan yang akan memberikan dampak yang baik pula terhadap pendapatan dan laba perusahaan (Subramanyam, 2017:159). Alasan yang memungkinkan mengapa rasio aktivitas berpengaruh positif terhadap financial distress adalah adanya aset yang kurang produktif di dalam perusahaan bisa dilihat rata-rata industri yang dihasilkan yaitu 1.607 kali karena menurut Kasmir standar industri untuk rasio aktivitas adalah 2 kali. Jika standar industri berada di bawah dua artinya perusahaan belum memaksimalkan aset yang dimilikinya (Kasmir, 2019:187).

Hasil penelitian ini sejalan dengan penelitian yang dilakukan oleh Silalahi dkk (2018) dan Jariyah (2019) yang menyimpulkan bahwa rasio aktivitas berpengaruh 


\section{Risinace}

Vol. 1 No. 4 Desember 2021

positif secara signifikan terhadap financial distress. Namun, hasil penelitian ini bertentangan penelitian Opitalia dan Zulman (2019) dan Aini (2019) yang membuktikan bahwa tidak ada pengaruh rasio aktivitas terhadap financial distress.

\section{KESIMPULAN, KETERBATASAN, DAN SARAN Kesimpulan}

Berdasarkan penelitian yang telah dilakukan, didapatkan kesimpulan sebagai berikut:

1. Rasio profitabilitas mempunyai pengaruh positif dan signifikan terhadap financial distress pada perusahaan manufaktur yang terdaftar di Bursa Efek Indonesia tahun 2016-2018. Artinya semakin tinggi kemampuan perusahaan dalam memperoleh laba maka potensi perusahaan mengalami financial distress juga semakin tinggi.

2. Rasio likuiditas mempunyai pengaruh positif dan signifikan terhadap financial distress pada perusahaan manufaktur yang terdaftar di Bursa Efek Indonesia tahun 2016-2018. Hal ini menunjukkan tinggi rasio likuiditas semakin tinggi kemungkinan terjadinya financial distress.

3. Rasio leverage mempunyai pengaruh negatif dan signifikan terhadap financial distress pada perusahaan manufaktur yang terdaftar di Bursa Efek Indonesia tahun 2016-2018. Artinya semakin tinggi rasio leverage semakin rendah kemungkinan terjadinya financial distress.

4. Rasio aktivitas mempunyai pengaruh positif dan signifikan terhadap financial distress pada perusahaan manufaktur yang terdaftar di Bursa Efek Indonesia tahun 2016-2018. Artinya semakin tinggi kemampuan perusahaan menggunakan asetnya secara efektif semakin tinggi potensi perusahaan mengalami financial distress.

\section{Keterbatasan Penelitian}

Penelitian ini memiliki beberapa keterbatasan, adapun keterbatasan penelitian dalam penelitian ini yaitu:

1. Proksi yang digunakan dalam mengukur rasio profitabilitas, likuiditas, leverage, dan aktivitas dalam penelitian ini masing-masing hanya satu proksi. Sedangkan masih banyak proksi lain yang dapat digunakan.

2. Hanya meneliti perusahaan manufaktur yang terdaftar di Bursa Efek Indonesia tahun 2016-2018.

\section{Saran}

Berdasarkan penelitian tersebut untuk mengatasi keterbatasan di atas, maka peneliti memberikan saran untuk penelitian selanjutnya sebagai berikut:

1. Penelitian selanjutnya diharapkan memperpanjang periode pengamatan agar hasil yang diperoleh lebih akurat.

2. Penelitian selanjutnya diharapkan memperluas sektor penelitian tidak hanya pada sektor manufaktur.

3. Untuk penelitian selanjutnya agar menggunakan ataupun menambah proksi lain dalam mengukur variabel independennya.

\section{DAFTAR PUSTAKA}

Aini, Dwi Qurrotul. 2019. Pengaruh Rasio Likuiditas, Leverage, Aktivitas, Profitabilitas Dan Sales Growth Terhadap Financial Distress (Studi Kasus Pada Perusahaan Sektor Pertambangan Yang Terdaftar Di Bursa Efek Indonesia Periode 2012-2016). Jurnal Ilmu Manajemen. Vol. 7 No. 1

Altman, Edward I. 1968. Financial Ratio, Discriminant Analysis, and The Prediction of Corporate Bankruptcy. Journal of Finance . Vol. XXIII No. 4:589-609 
Altman, Edward I. (2000). Predicting Financial Distress of Companies. Retrieved on.

As, Surya Gandi. 2019. Prediksi Kondisi Financial Distress Pada Perusahaan Manufaktur di Bursa Efek Indonesia. (Skripsi yang tidak dipublikasikan, Universitas Lampung)

Atina dan Elvi Rahmi. 2019. Analisis Rasio Keuangan dan Ukuran Perusahaan Terhadap Kondisi Financial Distress Perusahaan Manufaktur yang Terdaftar di Bursa Efek Indonesia Periode 2015-2017. EcoGen. Vol. 2 No.3:387-398

Beaver, W. H. 1966. Financial Ratios as Predictors of Failure. Journal of Accounting Research, 71-111.

Damayanti, J. T. A. 2019. Prediktor Financial Distress Pada Perusahaan Manufaktur: Model Logistik Versus Model Diskriminan (Doctoral dissertation, STIE Perbanas Surabaya).

Foster, G. 1986. Financial Statement Analysis. Prentic-Hall Inc.

Ghozali, Imam. 2018. Aplikasi Multivariate dengan Program IBM SPSS 25. Edisi Sembilan. Badan Penerbit Universitas Diponegoro. Semarang

Gujarati, Damodar N dan Dawn C. Porter. 2015. Dasar-dasar Ekonometrika. Edisi 5. Salemba Empat. Jakarta.

Gunde, Yulita M., Sri Murni, dan Mirah H.R. 2017. Analisis Pengaruh Leverage terhadap Profitabilitas pada Perusahaan Manufaktur Sub Industri Food and Bevarage yang Terdaftar di BEI (Periode 2012-2015). Jurnal Riset Ekonomi, Manajemen, Bisnis, dan Akuntansi. Vol. 5 No. 3:4185-4194

Hanafi, Imam dan S.G. Supriyadi. 2018. Prediksi Financial Distress Perusahaan Manufaktur yang Terdaftar di Bursa Efek Indonesia. Jurnal Ekonomi Bisnis. Vol. 4 No. 1:24-51

Hanafi, Mamduh M. dan Abdul Halim. 2016. Analisis Laporan Keuangan. Edisi Kelima. UPP STIM YKPN. Yogyakarta.

Hendra, Afrizal dan Diah, E. 2018. Faktor-Faktor yang Mempengaruhi Financial Distress (Studi Empiris pada Perusahaan Pertambangan yang Terdaftar di Bursa Efek Indonesia Periode 2014-2016). (Tesis yang tidak dipublikasikam, Universitas Jambi).

Hidayat, Mohammad Ali dan Wahyu Merianto. 2014. Prediksi Financial Distress Perusahaan Manufaktur di Indonesia. Diponegoro Journal of Accounting. Vol. 3 No. 3:1-11

Horne, J.C.V. dan J.M. Wachowicz. 2017. Prinsip-prinsip Manajemen Keuangan. Edisi 13. Salemba Empat. Jakarta

International Monetary Fund: World Economic Outlook Update. https://www.imf.org/external/pubs/ft/weo/2016/update/01/ diakses pada tanggal 13 Januari tahun 2020.

Jaafar, M.Z., A.A. Muhamat., S.F.S. Alwi., N.A. Karim dan Rahman. 2018. Determinants of Financial Distress among the Companies Practise Note 17 Listed in Bursa Malaysia. International Journal of Academic Research in Business and Social Sciences. Vol. 8 No. 11: 800-811

Jensen, M.C. dan W.H. Meckling. 1976. Theory of the Firm: Managerial Behavior Agency Cost and Ownership Structure. Journal of Financial Economics. Vol. 3:305-360

Karmini, K., \& Tjahjono, A. 2019. Analisis Rasio Keuangan Untuk Memprediksi Kondisi Financial Distress pada Perusahaan Manufaktur yang Terdaftar di 


\section{Risinaw}

Vol. 1 No. 4 Desember 2021

Bursa Efek Indonesia Tahun 2013-2017(Doctoral dissertation, STIE Widya Wiwaha).

Kasmir. 2019. Pengantar Manajemen Keuangan. Edisi Kedua. Kencana. Jakarta

Kristanti, Farida Titik. 2019. Financial Distress Teori dan Perkembangannya dalam Konteks Indonesia. Inteligensia Media. Malang

Lizal, L. (2002). Determinants of financial distress: What drives bankruptcy in a transition economy? The Czech Republic case.

Lubis, Nur Hafni dan Dina Patrisia. 2019. Pengaruh Activity Ratio, Leverage dan Firm Growth Terhadap Financial Distress (Studi Empiris pada Perusahaan Manufaktur yang Terdaftar di BEI Periode 2013-2017). Jurnal Kajian Manajemen dan Wirausaha. Vol. 1 No.1: 173-182

Masdupi, Erni, Abel Tasman, dan Atri Davista. 2018. The Influence of Liquidity, Leverage and Profitability on Financial Distress of Listed Manufacturing Companies in Indonesia. Advances in Economics, Business and Management Research. Vol. 57: 223-228

Muthoharoh, M. 2019. Determinan Financial Distress (Studi Empiris pada Perusahaan Manufaktur yang Terdaftar di BEI Periode 2013-2018) (Doctoral dissertation, Skripsi, Universitas Muhammadiyah Magelang).

Opitalia, M., \& Zulman, M. (2019). Determinan Financial Distress pada Perusahaan Sektor Property di Bursa Efek Indonesia. Jurnal Riset Ekonomi dan Bisnis. Vol. 12 No. 3:167-179.

Pattinasarany, C. A. 2010. Analisis Rasio Keuangan untuk Memprediksi Kondisi Financial Distress pada Perusahaan Go-Public. Skripsi. Sekolah Tinggi Ilmu Ekonomi Perbanas.

Platt, H., dan M. B. Platt. 2002. Predicting Corporate Financial Distress: Reflections on Choice Based Sample Bias . Journal of Economics and Finance. Vol. 26 No. 2:184:199

Putri, Rita Dwi. 2019. Analisis Pengaruh Pertumbuhan Penjualan dan Kepemilikan Manajerial terhadap Kondisi Financial Distress pada Perusahaan Manufaktur yang Ada di Indonesia. Jurnal Sosial dan Ilmu Ekonomi. Vol. IV No. 01:54-63

Rahmayanti, Sri dan Ulil Hadromi. 2017. Analisis Financial Distress Pada Perusahaan Manufaktur Yang Terdaftar di Bursa Efek Indonesia. Jurnal Akuntansi dan Ekonomika. Vol. 7 No. 1: 53-63

Ratna, I. dan Marwati. 2018. Analisis Faktor- Faktor yang Mempengaruhi Kondisi Financial Distress pada Perusahaan yang Delisting dari Jakarta Islamic Index Tahun 2012-2016. Jurnal Tabarru' : Islamic Banking And Finance, Volume 1 Nomor 1, Mei 2018.

Saputra, Agung Joni. 2019. The Effect Of Liquidity Ratio Leverage Ratio And Activity Ratio In Predicting Financial Distress. Management and Economic Journal. Vol. 3 No. 5:581-592

Sari, I. I. 2018. Rasio Keuangan Dalam Memprediksi Financial Distress Pada Perusahaan Sektor Industri Barang Dan Konsumsi Yang Terdaftar Di Bei 2013-2016 (Doctoral dissertation, STIE Perbanas Surabaya).

Sari, I.P., Arik Susbiyani dan Achmad Syahfrudin. 2019. Analisis Faktor-Faktor yang Mempengaruhi Kondisi Financial Distress pada Perusahaan yang Terdapat di BEI Tahun 2016-2018 (Studi Empiris pada Perusahaan Manufaktur Sub Sektor yang Terdaftar di Bursa Efek Indonesia). Jurnal Ilmiah Akuntansi dan Humanika. Vol. 9 No. 2: 191-203 
Silalahi, H.R.D., F.T. Kristanti dan Muhamad Muslih. 2018. Pengaruh Rasio Keuangan dan Ukuran Perusahaan Terhadap Kondisi Kesulitan Keuangan (Financial Distress) pada Perusahaan Sub-Sektor Transportasi yang Terdaftar di Bursa Efek Indonesia (BEI) Periode 2013-2016. E-Proceeding of Management. Vol. 5 No. 1: 796-802

Utami, Mesisti. 2015. Pengaruh Aktivitas, Leverage, dan Pertumbuhan Perusahaan dalam Memprediksi Financial Distress. E-journal Universitas Negeri Padang.

Wahyuningtyas, F., \& Isgiyarta, J. 2010. Penggunaan Laba dan Arus Kas untuk Memprediksi Kondisi Financial Distress (Studi Kasus pada Perusahaan Bukan Bank yang Terdaftar di Bursa Efek Indonesia Periode Tahun 20052008) (Doctoral Dissertation, Universitas Diponegoro).

Whitaker, R. B. 1999. The early stages of financial distress. Journal of Economics and Finance, 23(2), 123-132.

Widarjo, Wahyu dan Doddy Setiawan. 2009. Pengaruh Rasio Keuangan Terhadap Kondisi Financial Distress Perusahaan Otomotif. Jurnal Bisnis dan Akuntansi. Vol. 11 No. 2:107-119

Widiaputri, Mahiarestya. 2010. Analisis Rasio Keuangan untuk Memprediksi Kondisi Financial Distress pada Perusahaan Manufaktur yang Go Public. Jurnal. Universitas Pembangunan Nasional Veteran.

Worldbank.org: Manufacturing, value added ( $\%$ of GDP). https://data.worldbank.org/indicator/NV.IND.MANF.ZS diakses pada tanggal 12 Januari tahun 2019

www.idx.co.id

www.sahamok.com

Zhafirah, Anindya., dan Majidah. 2019. Analisis Determinan Financial Distress (Studi Empiris Pada Perusahaan Subsektor Tekstil dan Garmen Periode 2013-2017). Jurnal Riset Akuntansi dan Keuangan, Vol. 7 No. 1: 195-202 